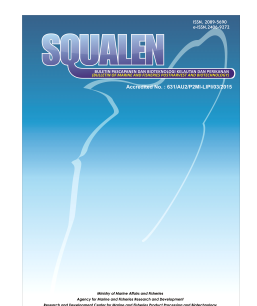

\title{
PROXIMATE COMPOSITION AND SENSORY CHARACTERISTICS OF TRADITIONAL AND OVEN-DRYING SMOKED TILAPIA FILLETS ENRICHED WITH OLIVE OIL
}

\author{
Diah Ikasari^ Suryanti and Th. Dwi Suryaningrum \\ ${ }^{1}$ Research and Development Center for Marine and Fisheries Product Processing and Biotechnology \\ JI. KS. Tubun Petamburan VI, Jakarta 10260 Indonesia \\ Article history: \\ Received: 10 October 2017; Revised: 30 November 2017; Accepted: 30 December 2017
}

\begin{abstract}
The study aimed to investigate the chemical and organoleptic characteristics of smoked tilapia fish fillets which were produced using different drying process and enriched with olive oil. Smoked fish were made using the following method: the fish were fasted overnight, shocked with cold water $\left(4-5{ }^{\circ} \mathrm{C}\right)$ and then slaughtered and filleted. The fillets were soaked for 30 minutes in a brine solution containing spices and $5 \%(\mathrm{v} / \mathrm{v})$ of liquid smoke. $5 \%(\mathrm{v} / \mathrm{v})$ of olive oil was added into the solution and compared with control without olive oil addition. After 30 minutes, fish were cleaned from the spices using water and smoked at a temperature of $80{ }^{\circ} \mathrm{C}$ for $4-5$ hours. The drying process was conducted in two different methods, i.e using oven-drying and traditional smoking. The smoked tilapia products were analyzed for proximate composition and sensory profiles. The result showed that addition of olive oil and methods of drying affected the proximate composition as well as sensory characteristics of the tilapia fillets. The fillets with addition of $5 \%$ olive oil and processed with oven-drying were considered as the best treatment due to low moisture content but high ash, fat and protein contents with $45.6 \pm 0.4 \% ; 6.8 \pm 0.1 \% ; 7.9 \pm 0.1 \%$ and $82 \pm 1.6 \%$, respectively. Based on panelist evaluation, the fillets with $5 \%$ olive oil and processed with oven-drying also had high performances in appearance and texture.
\end{abstract}

Keywords: tilapia, smoked fillets, oven-drying, traditional smoking, olive oil

\section{Introduction}

Tilapia is one of fish that have high economic value since the demand of tilapia in global market rises dramatically and tends to increase in years ahead. In 2017, an estimated 180.000 tonnes of tilapia were traded in the international market during JanuaryMarch both in the form of whole and fillet frozen (Food and Agriculture Organization of the United Nation, 2017). The United States of America, Mexico, and Iran were reported to be the leading importers of tilapia, while the leading exporters were mostly from China, Taiwan Province of China, Thailand and Indonesia. Total Indonesia tilapia export reached 13.239 tonnes in 2012 and increased to 16.694 tonnes in 2014 (Widiarti, 2015). The number can be possibly increased due to many advantages possessed by tilapia, including easy to cultivate; fast growing; and high tolerance to various environment conditions (Ramlah, Soekendarsi, Hasyim \& Hasan, 2016).
Tilapia has been exported in the form of fresh or frozen whole fish or fillets. Since 2007, China had developed processed products from tilapia fish fillets that dominate global market. The products are mostly ready to serve, in which tilapia fillets are coated with breadcrumb or added with herbs and spices. The processing of fresh tilapia into ready to serve products would increase the value added of the fish. Processing also gives preservation effect that can extend fish shelf life. However, the cooking methods of the products should be considered since they would affect the quality of the products as well as consumer preference. The protein and ash contents of steamed tilapia $(O$. mossambicus) steaks were reported to increase, but revealed a significant decrease in fat content and textural properties such as hardness, adhesiveness, gumminess, resilience, cohesiveness and chewiness (Dhanapal et al., 2012). Similar results were obtained in the experiment using Clupea harengus fish fillets

${ }^{*}$ Corresponding author.

E-mail: diah_ika263@yahoo.com 
that were cooked with smoking and poaching methods. The level of protein and ash content of the fillets cooked with both methods increased significantly, but the fat and crude fibre contents were reduced (Adeyemi et al., 2015). Drying process using various methods including sun and oven-drying might be recommended to be used since it can reduce the moisture contents of the fillets and prolong the product's shelf-life (Tarle, Guya, Abera, \& Fereja., 2016). However, it is also necessary to be considered due to its effect to the consumer acceptability including parameters of color, odor, taste and texture of the product.

Tilapia also has long been known as a valuable source of high quality protein as well as an important source of PUFAs, vitamin D, iodine and selenium for human diet (Adeyemi et al., 2015). Fish lipids, indicated by the omega-3/omega- 6 ratio, reflect the quality of the fish as foods since it plays a significant role in protecting against cardiovascular disease and rheumatoid arthritis (Kumaran, Ravi, Gunalan, Murugan, \& Sundramanickam, 2012; Ajayabhaskar, 2002). Both omega-3 and omega-6 PUFA are essential dietary components for humans since their synthesis is not possible within the human body (Chavan, Yakupitiyage, Ataguba, Kamble, \& Medhe, 2015). It is reported that the ratio of $n-3 / n-6$ in raw fish can be increased by cooking. Study conducted by Dhanapal et al. (2012) indicated that the ratio of $n-3 /$ n-6 in raw tilapia fish increased slightly from 0,40 to 0,46 by cooking and the levels of EPA, DPA and DHA almost doubled on cooked tilapia steaks, thus making the steaks as valuable sources of $n-3$ fatty acid. However, the ratio of $n-3 / n-6$ PUFA in tilapia muscle is considered very low compared to other freshwater fishes. Therefore, fortification of high fatty acids especially $n-3$, is required in the development of tilapia products (Dhanapal et al., 2012).

Vegetable oils have been widely used as dietary sources of omega-3 fatty acids (Chavan et al., 2015). Olive oil is one of vegetable oils that contain active components such as oleic acid, phenolic constituents, and squalene (Waterman \& Lockwood, 2007). Sakar et al. (2014) reported that the olive oil from Sirnak Province of the Southeastern-Anatolia contains palmitic acid, stearic acid, oleic acid, linoleic acid and linolenic acid. It is expected that the addition of olive oil is able to increase the ratio omega- 3 and omega- 6 in the tilapia fillets. However, the addition of olive oil into the fillets product is also expected to affect the quality of the fillets. The study aimed to investigate the characteristics of smoked tilapia fillets added with olive oil and produced with two types of drying methods, namely oven-drying and traditional smoking.

\section{Material and Methods}

\subsection{Material}

As many as 32 tilapias with sizes ranging from 440-660 g each were collected from Parung, Bogor. Other materials used in the study were salt, garlic, vinegar, pepper, olive oil, liquid smoke, and sugar. All ingredients were mixed to form a brine solution.

\subsection{Methods}

Tilapias were fasted overnight and shocked with cold water $\left(4-5^{\circ} \mathrm{C}\right)$ for $10-15$ minutes. The fishes were then slaughtered and drained for 10 minutes before filleted (Ikasari \& Suryaningrum, 2014). The fillets were soaked for 30 minutes in a brine solution containing water added with ingredients listed in Table 1. The ratio of fillets and water for brine solution was $1: 4$ (b/ v). The brine solution was added with $5 \%(\mathrm{v} / \mathrm{v})$ olive oil and compared with control without olive oil. After 30 minutes, fishes were cleaned from the spices using water and dried using a temperature commonly used for hot smoking process i.e $\pm 80{ }^{\circ} \mathrm{C}$ for 5 hours (Sebayang, 2002). The drying process was conducted in two different methods i.e using oven-drying and traditional smoking. The oven-drying process was carried out using oven assembled by Reseach Centre for Marine and Fisheries Product Processing and Biotechnology (RCMFPPB) with stove as the heat source. Meanwhile, the traditional smoking was conducted using smoking cabinet in which smoke produced by coconut shell burning as the the heat source. The smoked fish products were then analyzed for its proximate values (Association of Official Analytical Chemist, 2005) and organoleptic profiles (National Standardization Agency of Indonesia, 2009). In addition, the proximate values of the fresh fillets were also analyzed to investigate the nutritional value change of the products. The sensory evaluation was carried out using scoring and hedonic tests, conducted by 9 semi well-trained panellists to assess raw and smoked tilapia fillets. The attributes measured in the scoring test were appearance, odor, taste and texture. The scoring test was described with scale of 1 to 9 , whereas 1 represents the lowest features and 9 represents the highest features (Table 2). Meanwhile, the hedonic test was conducted using 1 to 7 scale score sheet, with 1 represents the least liked sample and 7 represents the most preferred sample (Table 3). The experiment was performed in triplicates.

\subsection{Data analysis}

The study used Completely Randomized Design experiment with two variables, i.e addition of $5 \%$ olive 
Table 1. Ingredient used for brine solution for tilapia fillets processing

\begin{tabular}{lc}
\hline Formulation & Amount (\%) \\
\hline Salt & $2 \%$ \\
Garlic powder & $3 \%$ \\
Vinegar & $0.5 \%$ \\
Pepper & $0.5 \%$ \\
Liquid smoke & $5 \%$ \\
Sugar & $5 \%$ \\
\hline
\end{tabular}

Note: The proportion was counted based on the volume of water used in brine solution

Table 2. Scoring attribute scheme for smoked tilapia fillets

\begin{tabular}{|c|c|c|c|c|c|}
\hline \multirow{2}{*}{ Attribute } & \multicolumn{5}{|c|}{ Score } \\
\hline & 1 & 3 & 5 & 7 & 9 \\
\hline Appearance & $\begin{array}{l}\text { Not attractive, } \\
\text { dark brown, } \\
\text { very dull }\end{array}$ & $\begin{array}{l}\text { Less attractive, } \\
\text { dark brown, dull }\end{array}$ & $\begin{array}{l}\text { Less attractive, } \\
\text { clean, brown, dull }\end{array}$ & $\begin{array}{l}\text { Attractive, } \\
\text { clean, golden } \\
\text { brown, less } \\
\text { luminous }\end{array}$ & $\begin{array}{l}\text { Attractive, } \\
\text { clean, golden } \\
\text { brown, glowing }\end{array}$ \\
\hline Odor & $\begin{array}{l}\text { Spoiled, strong } \\
\text { ammonia odor } \\
\text { and rancid }\end{array}$ & $\begin{array}{l}\text { Strong additional } \\
\text { disturbing odor, } \\
\text { smell of ammonia } \\
\text { identified }\end{array}$ & $\begin{array}{l}\text { Almost neutral } \\
\text { with slightly } \\
\text { additional } \\
\text { disturbing odor }\end{array}$ & $\begin{array}{l}\text { Slightly good } \\
\text { odor, enough } \\
\text { smoking odor, } \\
\text { without } \\
\text { additional } \\
\text { disturbing odor }\end{array}$ & $\begin{array}{l}\text { Good odor } \\
\text { (specific } \\
\text { product), } \\
\text { without } \\
\text { additional } \\
\text { disturbing odor }\end{array}$ \\
\hline Taste & Spoiled & $\begin{array}{l}\text { Not tasty, with } \\
\text { additional } \\
\text { disturbing taste }\end{array}$ & $\begin{array}{l}\text { Not tasty, not } \\
\text { savory }\end{array}$ & $\begin{array}{l}\text { Tasty, less } \\
\text { savory }\end{array}$ & $\begin{array}{l}\text { Very tasty, } \\
\text { savory, without } \\
\text { additional } \\
\text { disturbing taste }\end{array}$ \\
\hline Texture & $\begin{array}{l}\text { Very humid } \\
\text { surface, easily } \\
\text { to break }\end{array}$ & $\begin{array}{l}\text { Moist surface, } \\
\text { between networks } \\
\text { easy to break }\end{array}$ & $\begin{array}{l}\text { Less dry surface, } \\
\text { loose tissue } \\
\text { network }\end{array}$ & $\begin{array}{l}\text { Dense, } \\
\text { compact, less } \\
\text { dry surface, } \\
\text { strong tissue } \\
\text { network }\end{array}$ & $\begin{array}{l}\text { Dense, } \\
\text { compact, dry } \\
\text { surface, strong } \\
\text { tissue network }\end{array}$ \\
\hline
\end{tabular}

Table 3. Hedonic scheme for smoked tilapia fillets

\begin{tabular}{cl}
\hline Score & \multicolumn{1}{c}{ Meaning } \\
\hline 7 & Very like \\
6 & Like \\
5 & Slightly like \\
4 & Neutral \\
3 & Rather dislike \\
2 & Dislike \\
1 & Very dislike \\
\hline
\end{tabular}


oil and methods of drying; three replicates were run for each variable. The obtained data of proximate were statistically analysed using Multivariable analysis in order to determine the correlation and correspondence between treatments (olive oil addition and methods of drying) that affected to the proximate composition of the fillets which was eventually affected to the sensory evaluation of the products by panelist. In addition, the data were initially transformed into certain function in order to fulfill the multivariable analysis requirements. For proximate composition data, which were performed in percentage, were transformed into square root function (Huang et al., 2011). Meanwhile, the sensory data (score and hedonic) were transformed into log function (Chen \& Rosenthal, 2015). In multivariable analysis, the combinations of treatments were classified into 4 groups, i.e oven-drying without olive oil, traditional smoking without olive oil, oven-drying with $5 \%$ olive oil and traditional smoking with $5 \%$ olive oil. The discriminant factors of proximate and sensory values that represent those four groups were tested by Discriminant Analysis (DA). Furthermore, the correspondence between groups of treatments and their effects on samples proximate composition and sensory evaluation were analysed by Canonical Correspondence Analysis (CCA). The overall statistical analysis were performed by PAST Statistical Software v3.0 (Hammer, Harper \& Ryan, 2001).

\section{Results and Discussion}

\subsection{Proximate Composition of Smoked Tilapia Fillets}

The proximate composition of smoked tilapia fillets were presented in Figure 1. Overall, drying methods has affected the proximate composition of smoked tilapia fillet products. It was shown by lower values of moisture and protein contents but higher values of ash and fat contents of smoked tilapia fillets compared to fresh tilapia fillets.

The moisture contents of tilapia fillets dried with oven-drying and traditional smoking were ranging from 45.67-53.82\%; while those of fresh fillets contained $79.04 \%$ (Figure 1). Both methods of drying produced significantly lower moisture contents of the products compared to the fresh fillets $(p<0.05)$. Drying process produced heat energy which caused water molecules evaporation and eventually reduced moisture contents of the fillets.

Ash content of smoked tilapia fillets processed with oven-drying and traditional smoking were ranging from $6.84-7.18 \%$. These values were higher than these of fresh tilapia fillets $(4.80 \%)$. The increase of ash content can be attributed to an increase in the dry matter content per unit weight due to sample dehydration during smoking process (Adeyeye,

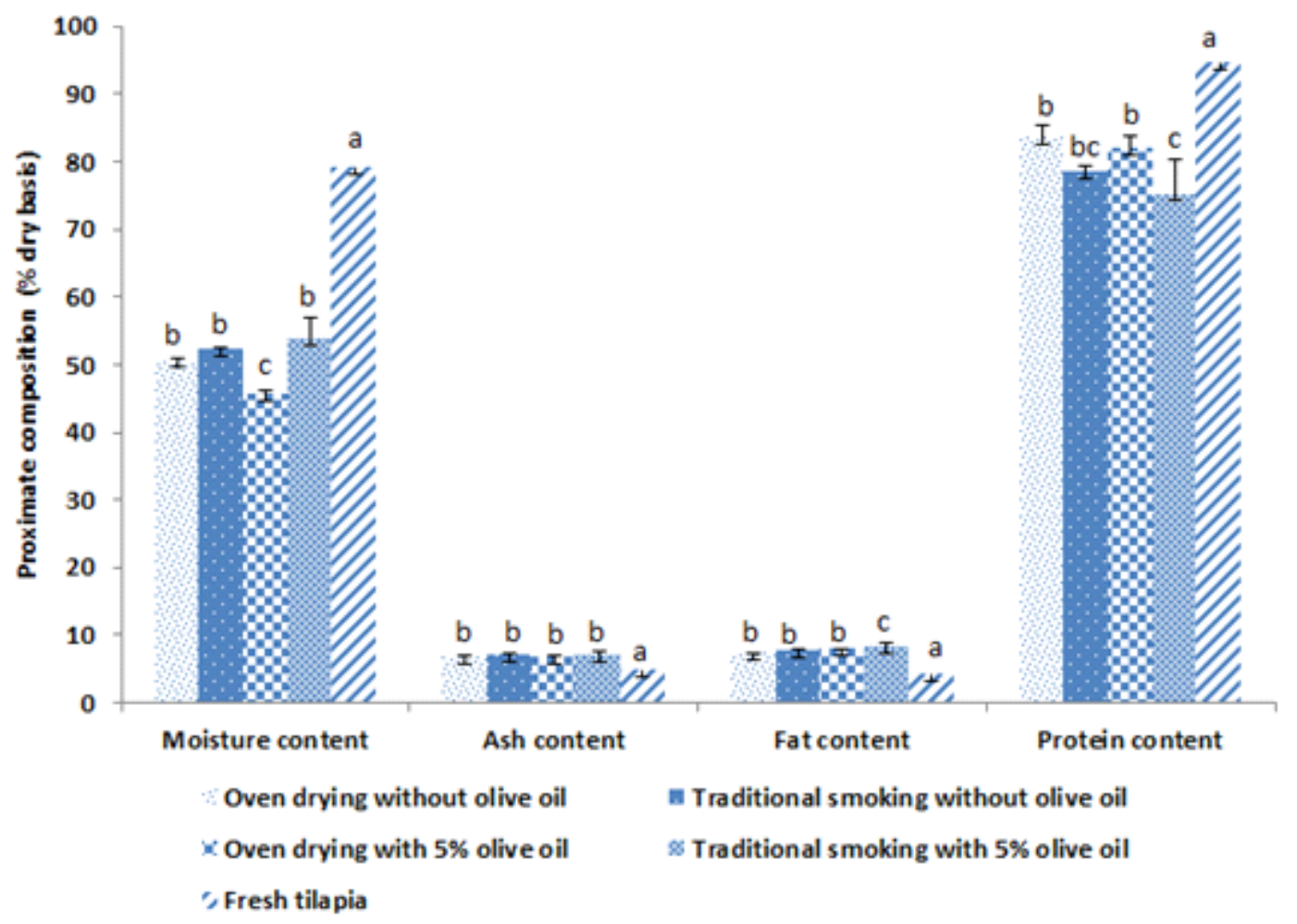

Figure 1. Proximate values of traditional and oven-drying tilapia fillets enriched with olive oil. 


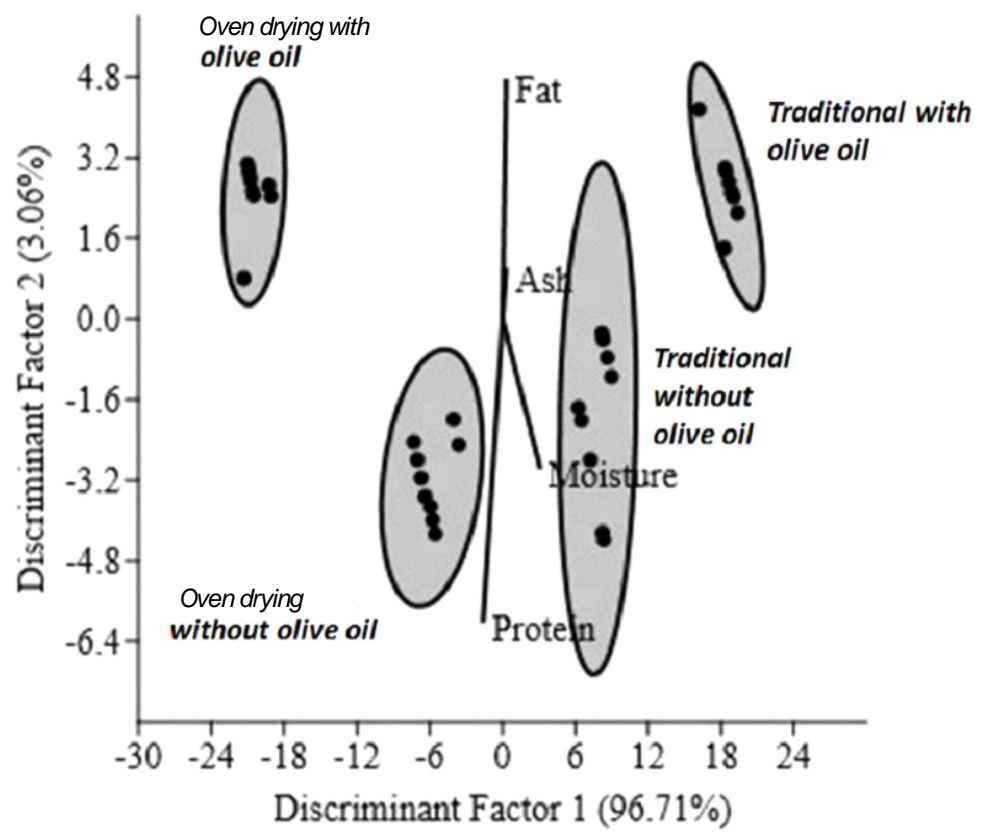

Figure 2. Discriminant Analysis of treatments (drying methods and olive oil addition combinations) on the proximate composition of smoked tilapia fillets.

Oyewole, Obadina, \& Omemu, 2015). The increase of ash content was also probably due to the deposition of mineral elements present in the salt during immersion process in the brine solution (Sudarmaji, Hariyono, \& Suhardi, 2013; Swastawati, Surti, Agustini, \& Riyadi, 2013).

Meanwhile, the fat contents of smoked tilapia fillets were ranging from 7.41 to $8.34 \%$. The values were almost doubled compared to the fat content of fresh tilapia fillet (4.25\%). This result is inaccordance with study conducted by Adeyeye et al. (2015), that showed a significant increase in fat content of the Bonga shad fillets after smoking process, from $6.46 \%-20.84 \%$ in fresh fillets to $16.13 \%-20.84 \%$ in smoked fillets. This was possibly due to the biochemical reactions occured during smoking which might increase the fatty acid content of the fillets (Dhanapal et al., 2012) as well as the addition of olive oil into the fillets in the experiment.

In addition, the protein content of smoked tilapia fillets were ranging from 75.14 to $83.64 \%$, which were significantly lower compared to fresh tilapia fillet i.e $94.54 \%(p<0.05)$. This phenomenon occured due to the processing activity using heat transfer. The smoking process which involved heat transfer caused the denaturation of proteins and further led to uncoiling of polypeptide chains (Dhanapal et al., 2012). As stated by Swastawati, Susanto, Cahyono, \& Trilaksono (2012), that the protein content of the product can decrease during heat processing due to denaturation process. The denaturated protein will be coagulated when further heated at temperature of
$50{ }^{\circ} \mathrm{C}$ or higher (Ghozali, Muchtadi, \& Yaroh, 2004). However, other studies showed an opposite results (Gall, Otwell, Koburger, \& Appledorf, 1983; Gokoglu, Yerlikaya, \& Cengiz, 2004; Adeyeye et al. 2015) which reported that the fillets experienced heat process had a higher protein contents compared to the raw fillets.

The result of Discriminant Analysis on the treatments was represented in Figure 2. It showed that there was no overlapping at level confidence of 95\% between treatments group and proximate composition variables (Figure 2). It means that each interaction between drying methods and olive oil addition factors gave a significant difference $(p<0.05)$ on the proximate composition of smoked tilapia fillets. Moisture content was correlated with discriminant factor 1 (96.71\%) which became the main differentiating variables for all treatments.

The characteristics of proximate composition based on treatments combination can be identified based on this dendogram. The oven-drying treatments affected in the decrease of moisture content values. This was indicated by the oven-drying treatment groups which kept away from the vector direction of moisture content. It is possibly related to the product exposure to the different heat source in both methods. In ovendrying method, which used stove as heat source, resulted more stable temperature, compared to traditional smoking method, which used smoking cabinet and utilized smoke produced from coconut shell burning. As a result, the heat energy being produced in the oven-drying method was higher than that of traditional smoking, which further resulted 
higher evaporation rate of water molecules contained in the fillets.

In the dendogram, the fillets with addition of $5 \%$ olive oil showed in opposite with the distance of moisture content vector (Figure 2). However, this effect was significantly different only when the fillets were processed with oven-drying $(p<0.05)$ (Figure 1). It indicates that the method of drying dominantly affected the moisture contents of the fillets rather than olive oil addition treatment. This results were in accordance with study conducted by Swastawati et al. (2013), which revealed that the smoked fish processed with smoking cabinet contained higher moisture contents compared to fish processed with direct drying using stove as heat source due to lower heat intensity received by the products. However, all smoked tilapia fillets produced in the experiment were considered meeting the standard SNI no. 01-2725.1-2009 (BSN, 2009) which stated that the maximum value moisture content of smoked fish is $60 \%$.

The addition of $5 \%$ olive oil as well as drying methods did not affect the ash contents of the smoked fillet products $(p<0.05)$, but influenced in the increase of its fat contents. It was indicated by higher value of fat contents obtained in the oven-dried fillets with addition of $5 \%$ olive oil $(7.97 \%)$ compared to ovendried fillets without $5 \%$ olive oil $(7.41 \%)$. Similarly, tilapia fillets processed with traditional smoking with addition of $5 \%$ olive oil were also had higher fat contents $(8.34 \%)$ compared to the one without $5 \%$ olive oil $(7.63 \%)$. This probably because olive oil is known to contain fatty acid component such as oleic acid, phenolic constituents, and squalene (Waterman \& Lockwood, 2007). Study conducted by Sakar et al. (2014) reported that olive oil obtained from Sirnak Province of the Southeastern Anatolia consisted of 10.34\%-20.92\% palmitic acid, stearic acid; $2.25 \%$ $3.91 \%, 49.33 \%-67.96 \%$ oleic acid, $7.52 \%-31.51 \%$ linoleic acid and $0.63 \%-2.72 \%$ linolenic acid, respectively. Other study performed by Suryaningrum et al. (2011) showed that addition of olive oil to the tilapia fillets increased significantly the fatty acid contents as well as omega- 3 contents of the fillets. Conversely, fillets with addition of olive oil were identified to have lower protein contents. This was shown by the group of treatments without olive oil which were approaching the protein vector direction in the dendogram. Similar finding was reported by Zotos, Kotaras and Mikras (2013) which revealed that heat processing (baking and frying) the anchovy samples in olive oil resulted in the reduction of moisture, ash and protein contents and followed by a significant increase in lipid contents. However, other study reported different direction with the results found in this work, showing an increase in protein and ash contents which followed by a reduction in lipid content were identified in the anchovy samples heated with olive oil for 4 minutes (Garcýa-Arias, Alvarez, GarcýaLinares, Garcýa-Fernandez \& Sanchez-Muniz, 2003).

\subsection{Sensory profile of smoked tilapia fillets}

\subsubsection{Attribute score of smoked tilapia fillets}

Sensory evaluation was conducted for scoring and hedonic test with parameter of appearance, odor, taste, and texture. Result of scoring test of tilapia fillet is presented in Figure 3, while for hedonic test result of tilapia fillet is presented in Figure 5. In order to distinguish the significancy of the treatments to the attribute score results, a Discriminant Analysis was performed (Figure 4).

The results of Discriminant Analysis of attribute scores variable showed that there was a high variation of the panelist evaluation in one group of treatments and on the contrary there was a consistent evaluation for different group of treatments (Figure 4). The heterogenity of preferences from each panelist was suspected to be the main source of this phenomenon. However, the panelist evaluation trend can be clearly observed due to the total discriminant factor reached $96.83 \%$ (discriminant factor 1 was $84.16 \%$ and discriminant factor 2 was $12.67 \%$ ). Appearance and taste became the main diferentiator of each group of treatments, represented by its correlation to the discriminant factor 1 . Both of these variables were correlated with oven-drying treatment, both with and without olive oil addition.

According to scoring test for parameter of appearance, the score given by panelist were ranging from 3.4 to 7.3. The treatment of drying method significantly increased the appearance of tilapia fillets $(p<0.05)$. The scores for these treatments were ranging from 6.7 -7.3. It represents that the fillets were having an attractive and clean appearance, but less shiny. Meanwhile, the lowest score was given to the tilapia fillets processed by traditional smoking, with scores of $3.4-4.5$, means that the fillet showed less attractive and dull appearance. According to Angela, Mentang and Sanger (2015) colour is one of aspect that influenced the panelist acceptance to the parameter of appearance, and the ideal and attractive colour of smoked fish is yellowish gold. In the experiment, the low score given by panelist to the product mainly due to uneven yellowish gold colour appeared in the fillet surface because of fluctuated heat received by the fillets thus made the fillets were less attractive. 


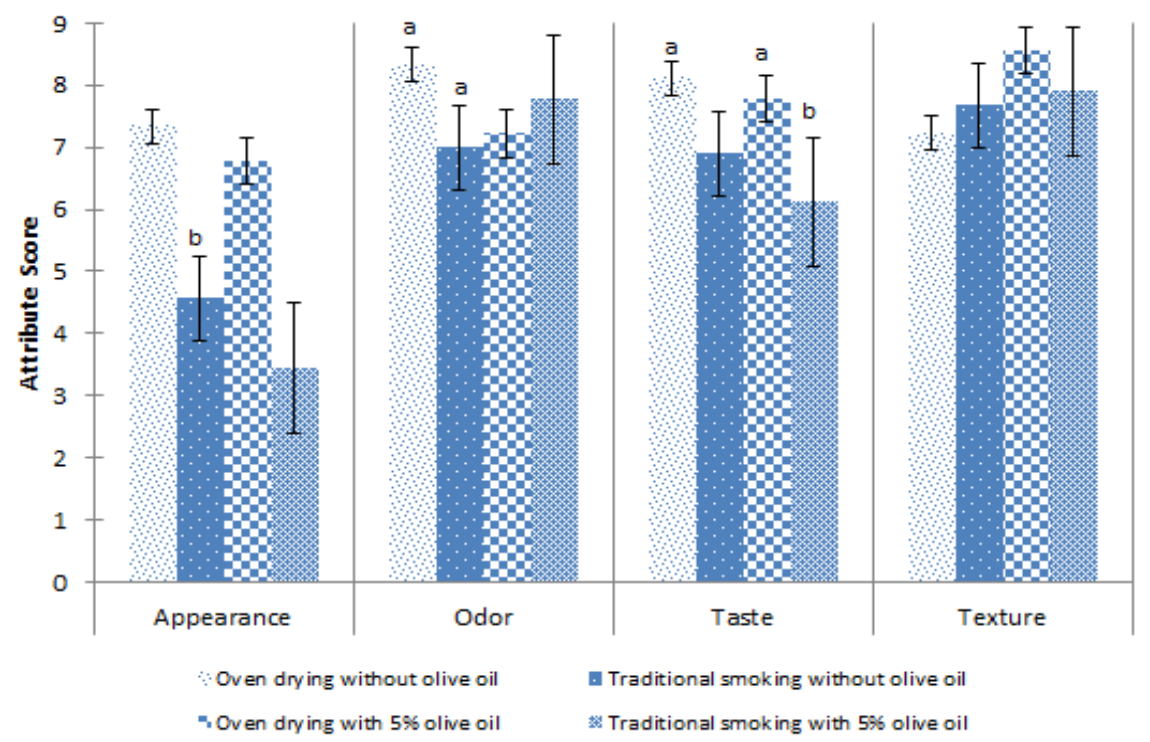

Figure 3. Attribute scoring test result of smoked tilapia fillets.

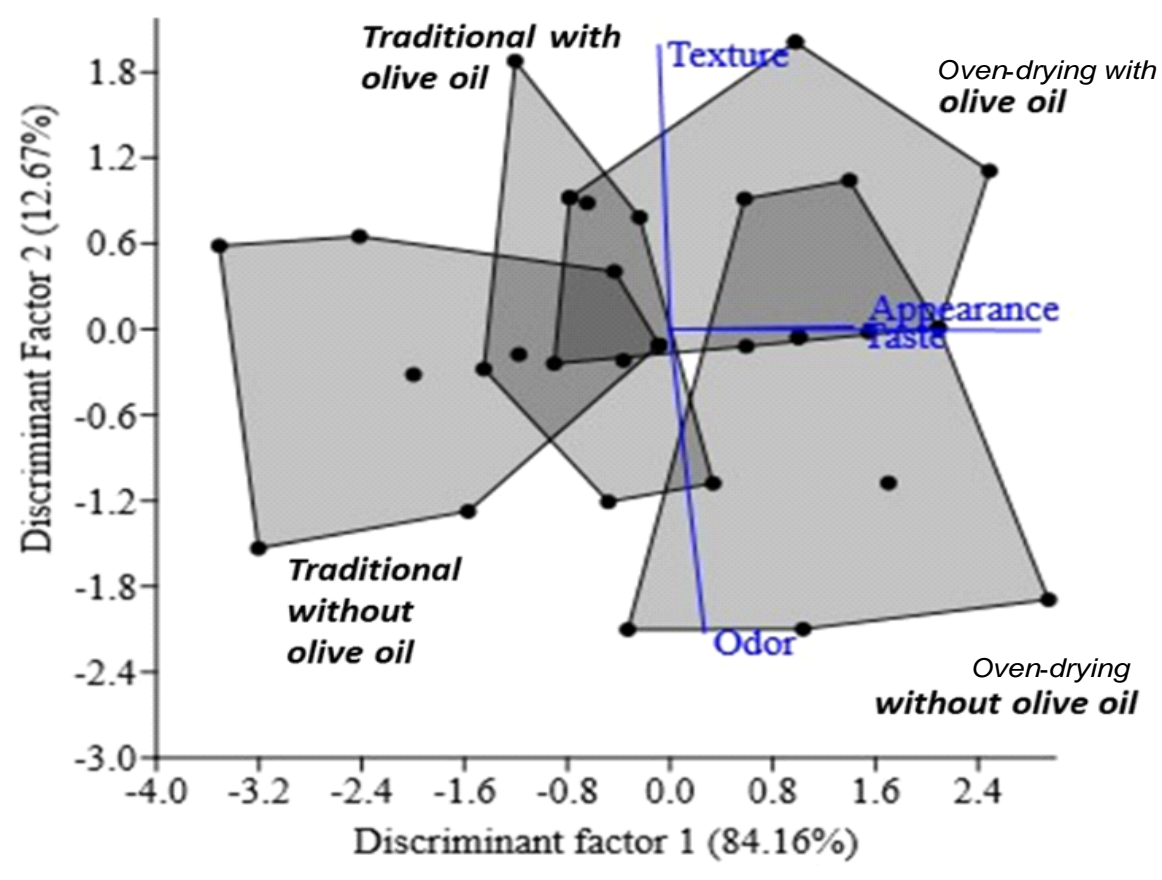

Figure 4. Discriminant Analysis of treatments (drying methods and olive oil addition combinations) on the attribute scores of smoked tilapia.

Similarly, panelists evaluated that processing with oven-drying improved smoked fillet's taste $(\mathrm{p}<0.05)$. The scores given by panelist for the four treatments were 6.1 to 8.1 and higher score were given for the oven-drying fillets, both with and without addition of olive oil (7.7-8.1). It represents that the fillets were tasty but slightly less savory. The traditional smoking fillets were rated lower scores by panelist compared to oven-drying method (6.1-6.8). It describes that the fillets were less tasty and less savory. The taste of smoke resulted from traditional smoking process was very strong thus the product became slightly bitter and sour. This likely due to the effects produced by the substances contained in the smoke such as phenol. According to Swastawati et al. (2013), the phenolic content found in the fish product was influenced by the variation of phenolic compound contained in the smoke produced in the smoking 


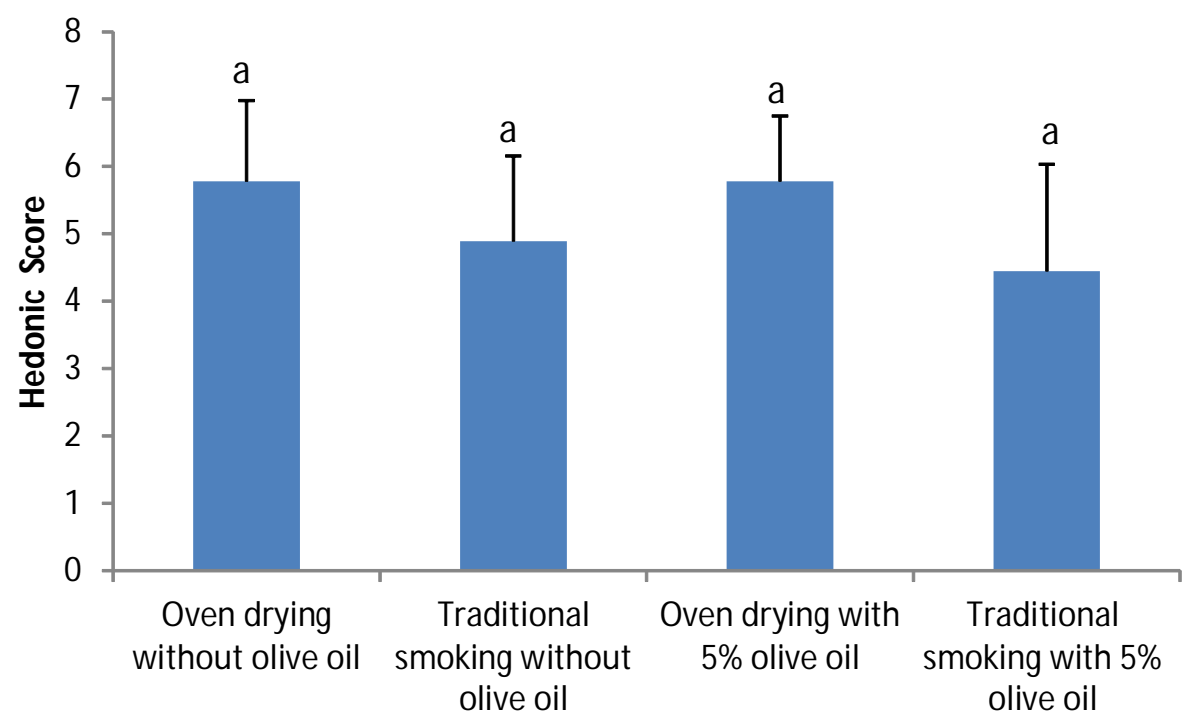

Figure 5. Hedonic test result of smoked tilapia fillets.

process. This result was in accordance with study conducted by Suryaningrum et al. (2011) which showed that oven-drying treatment tended to gave lower concentration of phenolic compound than traditional smoking.

Based on the Discriminant Analysis, panelist evaluated that the addition of olive oil gave a better effect on the texture of smoked tilapia fillets, both processed with oven-drying and traditional smoking. This trend showed by the groups of oil olive treatments which were approaching the protein vector direction. The score given for attribute texture with addition of olive oil were 7.8-8.5. It describes that the texture of the fillets were dense, compact, having a dry surface and strong inter-network between flesh tissue. However, these values were statistically not different with fillets without olive oil addition, both processed with oven-drying and traditional smoking, since the diagram showed overlapping between treatments $(p>0.05)$.

Conversely, for attribute of odor, panelist indicated that the addition of olive oil decreased the attribute of odor. It was indicated by the odor vector which was in the same direction with the two groups without olive oil addition. The score given by panelist for tilapia fillets without olive oil were 7.0-8.3, representing that the fillets were having a strong to less specific odor of smoked fish without any disturbing odor. The reduction of spesific odor was detected by panelist due to a slightly acid and burning odor identiifed in some samples, especially in fillets processed with traditional smoking. However, there was no significant different between treatments based on statistical analysis $(p>0.05)$

\subsubsection{Hedonic preference of smoked tilapia fillets}

According to hedonic test results, the panelist preferrences of smoked tilapia fillets were ranging from 4.4-5.7 (Figure 5). The scores describes that the smoked fillets resulted in the experiment were neither like nor dislike until slightly preferred by panelists. Although the fillets processed using oven-drying had higher score than traditional smoking, the statistical analysis showed there was no significant different between treatments $(p>0.05)$.

Furthermore, the correlation between proximate composition and attribute scores of smoked tilapia fillets that affects the panelist preference was analysed with Canonical Correspondence Analysis (CCA). The experiment showed that oven-drying method as well as olive oil addition gave a significant effect on the proximate composition of smoked tilapia fillets and as a result it influenced the sensory evaluation of these products. Overall, the hedonic scores given by panelists were in range of 2- 7 (Figure 6). From the those data range, it can be divided into three groups, i.e the low group with hedonic scores of 2-3 (a); the middle group with hedonic score of 4-5 (b); and the high group with hedonic scores of 6-7 (c). The combination of multivariable correlation between treatments that affected the proximate composition and further influenced the panelist preferences is presented in (CCA) dendogram (Figure 6).

The CCA dendogram showed that there was a correspondence between treatments, its impact on the change of proximate composition and attribute scores given by panelist, thus raising particular preferences of total panelist hedonic scores. The 


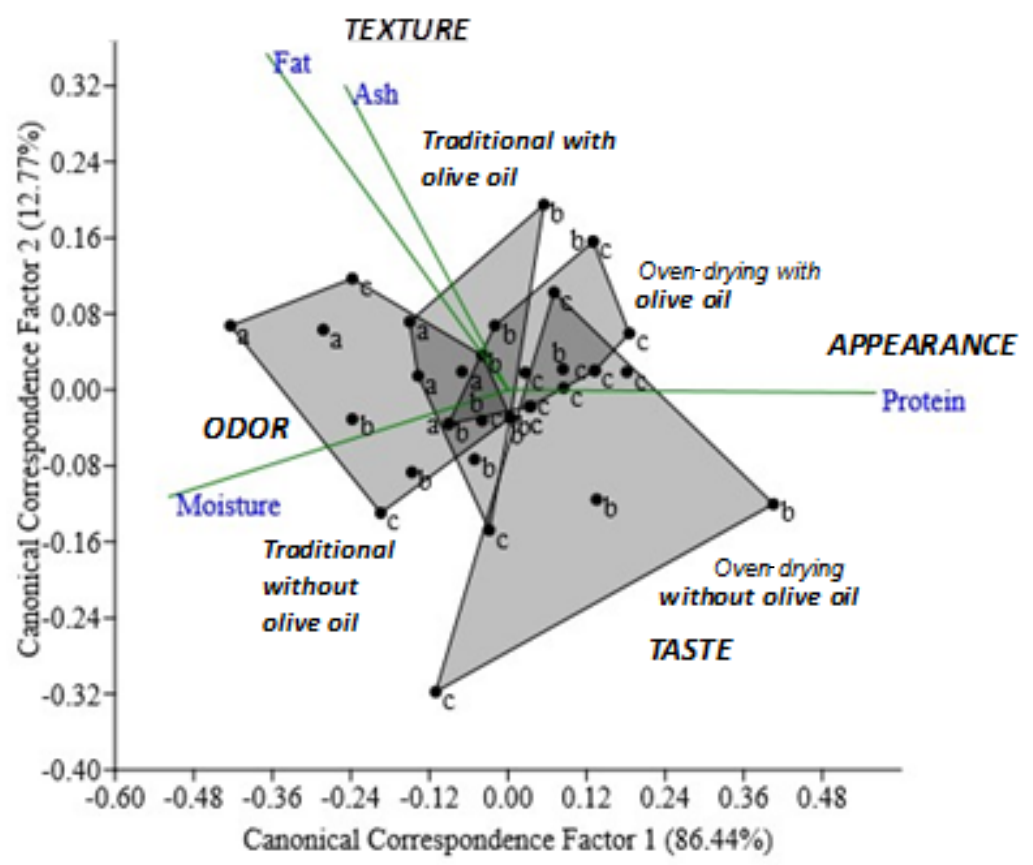

Figure 6. Canonical Correspondence Analysis (CCA) of correlation between group of treatments (drying methods and olive oil addition) on the attribute scores (taste, appearance, odor, dan texture) and hedonic scores of panelists $(a=$ hedonic scores of $2-3, b=$ hedonic scores of $4-5, c=$ hedonic scores of 6-7).

formation of correspondence factors was dominant with a factor 1 (86.44\%) that correspond with attribute of appearance and protein content; while factor 2 $(12.77 \%)$ correspond with attribute of texture as well as fat and ash contents. The four sensory attributes were located at different quadrant in the CCA dendogram and have a correlation with different proximate composition factors, resulting in hedonic scores that tend to be aligned. The higher group of hedonic scores (b and $c$ ) are located at quadrant I and IV, which is corresponded with the treatments of oven-drying. Meanwhile the low group of hedonic scores (a), tends to be located at quadrant II and III, which is corresponded with treatment of traditional smoking. The oven-drying treatments affected to the decrease of moisture, ash and fat contents, thus resulted in higher protein content in the products and having a better taste and appearance compared to traditional smoking. In addition, addition of olive oil which affected the fat and ash contents was assessed to have better appearance and textural properties but lower in taste and odor. Therefore, in order to improve the taste and odor of the smoked tilapia products, future study needs to be done, focusing on the optimum concentration of olive oil added into the products that resulted in higher values in each desirable parameter of nutritional contents, sensory attributes as well panelist preferences.

\section{Conclusions}

Based on the results, it can be concluded that addition of olive oil and drying method affected the proximate composition as well as sensory characteristics of the tilapia fillets. Considering the balance between the higher hedonic scores obtained in the sensory evaluation and the higher values of proximate composition, therefore tilapia fillets with addition of $5 \%$ olive oil and processed with oven-drying was considered as the best treatment. The fillets had low moisture content but high ash, fat and protein contents with $45.6 \pm 0.4 \% ; 6.8 \pm 0.1 \% ; 7.9 \pm 0.1 \%$ and $82 \pm 1.6 \%$, respectively. It also showed high performance in appearance and texture according to sensory evaluation. However, further study is needed in order to improve the odor and taste of the products by varying the concentration of olive oil to be lower than the concentration used in this study.

\section{Acknowledgement}

This study was funded by Research Center for Marine and Fisheries Product Processing and Biotechnology, Ministry for Marine Affairs and Fisheries of Indonesia in 2011. The authors are thankful to Hedi Indra Januar, our colleague in Research Center for Marine and Fisheries Product Processing and Biotechnology, for his help in the data analysis provision for the preparation of the paper. 


\section{References}

Adeyemi, O.T., Osilesi, O., Adebawo, O.O., Onajobi, F.D., Oyedemi, S.O., \& Afolayan, A.J.(2015). Variation in proximate composition of Clupea harengus (fillet \& skin, head, bones (SHB)) after different heat treatment. Journal of Natural Science Research, 5(1):117-121.

Adeyeye, S.A.O., Oyewole, O.B., Obadina, A.O., \& Omemu, A.M. (2015). Influence of smoking method on quality of traditional smoked Bonga shad (Ethmalosa frimbiata) fish from Lagos State, Nigeria. African Journal of Food Science, 9(4):200-207,

Ajayabhaskar D. (2002). Nutritional evaluation of molluscan sea food. Ph.D. Thesis, Annamalai University, India, 129.

Angela, G.C., Mentang, F., \& Sanger, G.(2015). Kajian mutu ikan cakalang (Katsuwonus pelamis, L) asap dari tempat pengasapan desa Girian Atas yang dikemas vakum dan non-vakum selama penyimpanan dingin. Jurnal Media Teknologi Hasil Perikanan, 3(2): 29-40.

Association of Official Analytical Chemist. (2005). Official Methods of Analysis of The Association of Official Analytical Chemist. Inc. Washington. DC.

BSN (2009). Organoleptic test for Smoked Fish Product. SNI No.01-2725.1-2009. National Standardization Board.

Chavan, B.R., Yakupitiyage, A., Ataguba, G.A., Kamble, M.T., \& Medhe, S.V. (2015). Tilapia as food fish : Enhancement of Ù-3 polyunsaturated fatty acids in Tilapia (Oreochromis Spp.). International Journal of Agriculture Sciences, 7(9): 671-677.

Chen, J. \& Rosenthal, A. (2015) Modifying Food Texture: Vol. 2, Sensory Analysis, Consumer Requirement and Preferences. Woodhead Publishing

Dhanapal, K., Reddy, G.V.S., Naik, B.B., Venkateswarlu, G., Reddy, A.D\& Basu, S.(2012). Effect of cooking on physical, biochemical, bacteriological characteristics and fatty acid profile of Tilapia (Oreochromis mossambicus) fish steak. Archives of Applied Science Research, 4(2):1142-1149.

Food and Agriculture Organization of the United Nation. (2017). TiLV threatens food security. Globefish Analysis and information on world fish trade. Retrieved from http://www.fao.org/in-action/globefish/marketreports/resource-detail/en/c/1046004/

Gall, K. L., Otwell, W. S., Koburger, J. A., \& Appledorf, H. (1983). Effects of four cooking methods on proximate, mineral and fatty acid composition of fish fillets. Journal of Food Science, 48: 1068- 1074

Garcý'a-Arias, M.T., Alvarez, P.E., Garcýa-Linares, M.C., Garcýa-Fernandez, M.C. \& Sanchez-Muniz, F.J. (2003). Cooking - freezing-reheating (CFR) of sardine (Sardina pilchardus) fillets. Effect of different cooking and reheating procedures on the proximate and fatty acid compositions. Food Chemistry, 83: 349-356.

Ghozali, T., Muchtadi, D., \& Yaroh. (2004). Improvement of shelf life "sate Bandeng (Chanos chanos)" by using cold storage and freezer. Informatek, 6(1):1-6.
Gokoglu, N., Yerlikaya, P. \&Cengiz, E. (2004). Effect of cooking methods on the proximate composition and mineral contents of rainbow trout (Oncorhynchus mykiss). Food Chemistry, 84: 19-22

Huang YCA, Hsieh HJ, Huang SC, Meng PJ, Chen YS, Keshavmurthy S, Nozawa Y, \& Chen CA. (2011). Nutrient enrichment caused by marine cage culture and its influence on subtropical coral communities in turbid waters. Marine Ecology Progress Series, 423: 83-93.

Hammer, O., D.A.T. Harper, \& P.D. Ryan, (2001). Past: Palaeontological statistics software package for education and data analysis. Palaeontological Electronic, 4(1), 9pp.

Ikasari, D. \& Suryaningrum, T. D. (2014). Effect of slaughtering techniques on the quality of fresh "Pangasius Hypopthalmus Hypopthalmus" fish (Pangasius sp.) stored at ambient temperature. Squalen : Bulletin of Marine and Fisheries Postharvest and Biotechnology, 9(2) : 63-74.

Kumaran, R., Ravi V., Gunalan B., Murugan S. \& Sundramanickam A. (2012). Estimation of proximate, amino acids, fatty acids and mineral composition of mullet (Mugil cephalus) of Parangipettai, Southeast Coast of India. Advances in Applied Science Research,3 (4):2015-2019.

Ramlah, Soekendarsi, E., Hasyim, Z. \& Hasan, M.S. (2016). Comparison of nutritional content of Tilapia (Oreochromis nitolicus)from Mawang's lake Gowa and Hasanuddin University lake, Makassar city. Jurnal Biologi Makasar, 1(1): 39-46.

Sakar, E., Ak, B.E., Ünver, H., Çelik, M., Türkoðlu, H., \& Keskin, S. (2014). Determination of total Olive oil and Cis-Trans fatty acids composition of Sirnak Province Olive genotypes at Southeastern Anatolia. Journal of Agriculture and Environmental Sciences, 3(4):119129.

Sebayang, N. (2002). Application of fish smoking technology for coastal society. Jurnal Pengabdian Kepada Masyarakat, 8(28): 25-34.

Swastawati, F., Susanto, E., Cahyono, B., \& Trilaksono, W.A. (2012). Sensory evaluation and chemical characteristics of smoked stingray (Dasyatis blekeery) processed by using two different liquid smoke. International Journal of Bioscience, Biochemistry and Bioinformatics, 2(3):212-216.

Swastawati, F., Surti, T., Agustini, T.W., \& Riyadi, P.H. (2013). Characteristics of smoked fish processed with different methods of smoking using different fish species. Jurnal Aplikasi Teknologi Pangan, 2(3): 126132.

Sudarmaji, S., Hariyono, B., \& Suhardi. (2003). Analisa Bahan Makanan dan Pertanian. Liberty, Yogyakarta.

Suryaningrum, T.D., Wibowo, S., Perangingangin, R., Irianto, H.E., Muljanah, I., Suryanti, \& Ikasari, D. (2011). Research of added value and diversification of fisheries products. Final Report. Research Centre for Marine and Fisheries Product Processing and Biotechnology. 
Tarle, D., Guya, M., Abera, S. \& Fereja, G.B. (2016). Effect of drying methods and pre-treatments on nutritional value and sensory quality of fish (Oreochromis niloticus, Pylodictis olivaris and Cyprinus carpio) species commonly used in Gambella region. Turkish Journal of Agriculture, 4(1):22-30.

Waterman, E. \& Lockwood, B. (2007). Active components and clinical applications of oil olive. Alternative Medicine Review, p.331+. Academic One File, Retrieved from http://go.galegroup.com/ps/ anonymous $? \mathrm{id}=\mathrm{GALE} \% 7 \mathrm{CA} 172908573 \& \mathrm{sid}=$ googleScholar $\& v=2.1 \& i t=r \& l i n k a c c e s s=$ full text\&issn $=10895159 \& p=A$ ONE \& $s w=w \&$ auth Count $=1$ \&isAnonymousEntry=true

Widiarti, A.(2015). Indonesia Tilapia production and trade. Manuscript presented in INFOFISH Conference, Kuala Lumpur. Retrieved from http:// www.infopesca.org/sites/default/files/complemento/ actividadesrecientes/adjuntos/1369/5\%20Indonesi a-Tilapia\% 20Production \%20and \% 20Trade.pdf

Zotos, A., Kotaras, A. \& Mikras, E. (2013). Effect of baking of sardine (Sardina pilchardus) and frying of anchovy (Engraulis encrasicholus) in olive and sunflower oil in their quality. Food Science and Technology International, 19(1):11-23 